\title{
Editorial
}

Psychotherapy and Psychosomatics

Psychother Psychosom 2006;75:1-3

DOI: $10.1159 / 000089219$

\section{A Different Medicine Is Possible}

\author{
Giovanni A. Fava \\ Department of Psychology, University of Bologna, Bologna, Italy, and Department of Psychiatry, \\ State University of New York at Buffalo, Buffalo, N.Y., USA
}

The proliferating connections between physicians and the pharmaceutical industry have brought the credibility of clinical medicine to an unprecedented crisis. Editors who played a major role in publishing medical studies subsequently found to be biased by conflict of interest highlight the various forms of manipulations operated by the industry $[1,2]$. The public seems to be increasingly skeptical of clinical medicine, the more so as corporate actions that have placed profit over public health have become staple news fare. The commercial success in North America of a recent book feeding such skepticism and suspicion exemplifies this attitude and the escape into alternative or complementary medicine [3]. The way its author depicts medical associations (such as the American Medical Association, American Cancer Society and American Psychiatric Association) is particularly indicative:

... these associations are not in place to eliminate disease or keep people healthy. When you read their charters you find that they are there to promote the disease, in an effort to get additional funding and protect their members, which are the drug companies and doctors! (...) Associations such as the American Medical Association have no interest in what benefits the consumer. They only have an interest in what benefits their members. [3, pp 22-24].

The loss of credibility of medical information appears to be part of a more general crisis of conventional news media. In a recent poll performed in the US, 79\% thought that a media company would not publish negative stories about a corporation from which it received substantial advertising revenues [4].

\begin{tabular}{ll}
\hline KARGER & (c) 2006 S. Karger AG, Basel \\
Fax +4161306 12 34 & 0033-3190/06/0751-0001\$23.50/0 \\
$\begin{array}{l}\text { E-Mail karger@karger.ch } \\
\text { www.karger.com }\end{array}$ & $\begin{array}{l}\text { Accessible online at: } \\
\text { www.karger.com/pps }\end{array}$
\end{tabular}

More and more voices from academic medicine are questioning the relationship between the pharmaceutical industry and the physicians [5]. We wished such reactions had occurred in the nineties, when the phenomenon of conflict of interest was more controllable, and when our journal actually did react $[6,7]$.

The question is now whether the growing number of episodes concerned with conflict of interest is the unavoidable drawback of a system which functions in an independent and satisfactory way, or whether they are the expression of a clinical medicine devoid of its psychosocial dimension and therefore extremely liable to corporate influences. Is the image of a dehumanized, technological medicine, loaded with conflict of interest and with marketing strategies, the only model we have to offer? Or is there a different model which physicians may refer to?

\section{The Psychosomatic Model}

In the late sixties, the psychosomatic investigator Lawrence E. Hinkle advocated the endorsement of an ecological approach in psychosomatic medicine during his presidential address at the annual meeting of the American Psychosomatic Society [8]. The term 'ecology' was not very common in those days and back then it meant relating biochemical, physiological and psychological disorders to the social environment [9]. In the same year of the presidential address, George Engel developed a mul- 
tifactorial model of illness [10], later subsumed under the rubric of 'biopsychosocial' [11]. It allows illness to be viewed as the result of interacting systems at the cellular, tissue, organismic, interpersonal and environmental levels. These ecological relationships, such as the growing importance of environmental toxic factors, the social inequalities that affect health and the unexplained variance in health outcomes [12-14], have been largely neglected.

A new branch of clinical pharmacology, 'social pharmacology' has recently been proposed to deal with the relationship between drugs and society [15]. Such development was prompted by the increasing use of medication for social problems previously not requiring drug utilization (e.g. aging, loss of libido, school performance).

From an ecological point of view, a psychosomatic framework appears to be crucial for addressing the current social challenges of clinical medicine, including the issue of conflict of interest.

Psychosomatic medicine may be defined as being concerned with:

1 The assessment of psychosocial factors affecting individual vulnerability, course, and outcome of any type of disease.

2 The holistic consideration of patient care in clinical practice.

3 The specialist interventions to integrate psychological therapies in the prevention, treatment and rehabilitation of medical diseases [16].

Psychosomatic medicine has recently become a subspecialty recognized by the American Board of Medical Specialties [17]. This may lead to equating psychosomatic medicine with consultation-liaison psychiatry [18], a subspecialty of psychiatry concerned with diagnosis and treatment of psychiatric morbidity in the medical patient. As Wise [19] pointed out, consultation-liaison psychiatry is clearly within the field of psychiatry and largely limited to the general hospital. Psychosomatic medicine is, by definition [16], multidisciplinary and extended to all areas of medical care. The traditional boundaries among medical specialties, based mostly on organ systems (e.g., cardiology, endocrinology) appear to be more and more inadequate in dealing with symptoms and problems which cut across organ system subdivisions [20]. Psychosocial factors may operate to facilitate, sustain, or modify the course of disease, even though their relative weight may vary from illness to illness, from one individual to another, and even between two different episodes of the same illness in the same individual [21]. Psychosomatic medicine calls for interdisciplinary specialists, such as psycho-neuroendocrinologists and psycho-oncologists, who may deal more effectively with current challenges of clinical medicine. We need a psychosomatic subspecialty in clinical areas other than psychiatry (e.g. internal medicine, gastroenterology and rheumatology). There is also a need for interdepartmental divisions, for both research and clinical purposes. In the sixties, Hinkle was heading the Division of Human Ecology of the Departments of Medicine and Psychiatry of Cornell University. It is difficult today to envision something which may overcome the artificial boundaries that the game of power has built into the medical system. Psychosomatic medicine is the home of interdisciplinary work and of physicians who believe that, 'How a person experiences the pathological process, what it means to him, and how this meaning influences his behavior and interaction with others are all integral components of disease viewed as a total human response' [21]. Not surprisingly, the corporate interest for psychosomatic medicine has been minimal.

\section{Conclusions}

It has recently been reported that almost 1 of 10 US physicians is currently engaged in a formal consultancy with investment industry [5]. However, we should bear in mind that actually 9 out of 10 physicians do not have such relationships with financial entities, even though they may have had chances of developing them. This choice may entail less money, gifts, subsidized conferences, travel opportunities and the like. But it is the only way of defending our own intellectual freedom and the trust in us as a profession [22]. As Noam Chomsky [23] reminds us, 'if we do not like what we see when we look into the mirror honestly, we have every opportunity to do something about it'. If we do not like what we see in medicine today, we should remember that a different medicine is possible. It is called psychosomatic medicine. 


\section{References}

1 Angell M: The Truth About the Drug Companies: How They Deceive Us, and What To Do About It. New York, Random House, 2004.

2 Kassirer J: On the Take: How Medicine's Complicity with Big Business Can Endanger Your Health. New York, Oxford University Press, 2004.

3 Trudeau K: Natural Cures 'They' Don't Want You to Know About. Elk Grove Village, Alliance Publishing Group, 2004.

4 Posner RA: Bad news. The New York Times Book Review, 31 July, 2005.

5 Topol EJ, Blumenthal D: Physicians and the investment industry. JAMA 2005;293:26542657.

6 Fava GA: All our dreams are sold. Psychother Psychosom 1998;67:191-193.

7 Krimsky S, Rothenberg LS, Stott P, Kyle G: Scientific journals and their authors' financial interests. Psychother Psychosom 1998;67: 194-201.
8 Hinkle LE: Human ecology and psychosomatic medicine. Psychosom Med 1967;29:391395.

9 Hinkle LE: Relating biochemical, physiological and psychological disorders to the social environment. Arch Environ Health 1968;16: 77-82.

10 Engel GL: The concept of psychosomatic disorder. J Psychosom Res 1967;11:3-9.

11 Engel GL: The need for a new medical model: a challenge for biomedicine. Science 1977;196: 129-136.

12 Levin BW, Browner $\mathrm{CH}$ : The social production of health. Soc Sci Med 2005;61:745-750.

13 Armelagos GJ, Brown PJ, Turner B: Evolutionary, historical and political economic perspectives on health and disease. Soc Sci Med 2005;61:755-765.

14 Worthman CM, Kohrt B: Receding horizons of health. Soc Sci Med 2005;61:861-878.

15 Ngoundo Mbongue TB, Sommet A, Pathak A, Montastruc JL: Medicamentation of society, non-diseases and non-medications: a point of view from social pharmacology. Eur J Clin Pharmacol 2005;61:309-313.
16 Fava GA, Sonino N: The clinical domains of psychosomatic medicine. J Clin Psychiatry 2005;66:849-858.

17 McIntyre JS: A new subspecialty. Am J Psychiatry 2002;159:1961-1963.

18 Gitlin DF, Levenson JL, Lyketsos CG: Psychosomatic medicine: a new psychiatric subspecialty. Acad Psychiatry 2004;28:4-11.

19 Wise TN: Consultation-liaison psychiatry and psychosomatics: strange bedfellows. Psychother Psychosom 2000;69:181-183.

20 Kroenke K, Mangelsdorff D: Common symptoms in ambulatory care. Am J Med 1989;86: 262-268.

21 Lipowski ZJ: Psychosocial aspects of disease. Ann Intern Med 1969;71:1197-1206.

22 Fava GA: Conflict of interest and special interest groups. Psychother Psychosom 2001;70: $1-5$.

23 Chomsky N: Universals of human nature. Psychother Psychosom 2005;74:263-268. 